Vietnam Academy of Science and Technology
Vietnam Journal of Earth Sciences
http://www.vjs.ac.vn/index.php/jse

\title{
Preliminary study on phytogeography of Dipterocarpaceae Blume family in Vietnam
}

\author{
Vu Anh Tai*, Pham The Vinh, Tran Thi Thuy Van, Le Thi Kim Thoa, Le Duc Hoang, Ngo Thi \\ Bich Hong \\ Institute of Geography (VAST)
}

Received 11 July 2016. Accepted 07 August 2017

\begin{abstract}
Biogeographically mapping flora of Vietnam requires the studies on the distribution of some important species groups for identifying the typical species composition of each phytochorion. The Dipterocarpaceae family contains taxa originated in tropical Asia and its subfamily of Dipterocarpoideae is proved to have Southeast Asia origin. In Vietnam, this family includes 43 species in 7 genera. In this study, Dipterocarpaceae species from 645 sites in Vietnam are assessed and compared to those in over the world. In Vietnam, this family distributes in tropical and/or slightly passing to subtropical climate but none of its species is naturally found in the Red River and the Mekong River deltas. In the world, the Dipterocarpaceae species found in Vietnam concentrated distributes in Indochina floristic region, corresponding to the originative area of South Myanmar. Statistically, there are 12 endemic species for the Indochinese floristic region and five of them are endemic for four provinces of this region related to Vietnam, respectively as follows: South China - 1, North Indochina - 1, South Indochina - 2 and Annam - 1. Additionally, some species distribute in East Asia floristic region of Holarctic Kingdom because of expanding the distribution area from the Indochinese floristic region. All genera of this family in Vietnam were originated in the Indochinese floristic region. Moreover, the floristic data and phytogeographical phylogeny diagram, based on analyses of phytogeography and DNA, would be better to use for finding out the distributional source or the forming time of species or genus, then the phylogenetic diagram.
\end{abstract}

Keywords: Dipterocarps family; Indochina floristic region; North Indochinese floristic province; Annamese floristic province; South Indochinese floristic province; Phytogeographical phylogeny; Endemic species.

(C)2017 Vietnam Academy of Science and Technology

\section{Introduction}

In a purpose of biogeographically mapping Vietnam flora, the taxon distributions are required to find out the typical species composition for each area. Dipterocarps family (Dipterocarpaceae Blume) (Angiosperm Phylogeny Group, 2009), with its taxon distributing in the

"Corresponding author, Email: tai.botany@gmail.com
Asia and its sub-family of Dipterocarpoideae, including 475 species of 13 genera, distributing from Seychelles, Sri Lanka, India, Southeast Asia to New Guinea and most of Borneo islands was identified to be originated from Southeast Asia (Myanmar). In Vietnam, there are 43 species and 7 genera of Dipterocarps family, all of them belong to Dipterocarpoideae sub-family (Nguyen Hoang Nghia, 2005). The distributions of these genera were 
defined as follows (Nguyen Hoang Nghia, 2005): Anisoptera from Bangladesh, Myanmar, to Indochina and New Guinea; Dipterocarpus in Sri-Lanka, India, Myanmar, Thailand, Indochina, Malay peninsula, Sumatra, Borneo and Philippines; Vatica from Sri-Lanka, India, Myanmar, Thailand, Indochina, Malay peninsula to Hainan and New Guinea; Hopea in SriLanka, India, Myanmar, Thailand, Indochina, Malesia and South of China; Shorea in SriLanka, Myanmar, Thailand, Indochina and most of Malesia; Parashorea from Myanmar, South of China, Thailand, Indochina to Philip- pines and Borneo. Genetic relationships of Asian Dipterocarps species were analyzed in term of nuclear DNA and chloroplast DNA (Dayanandan et al., 1999). Based on DNA analysis, a genetic phylogeny diagram expressing the relationships of the species in genera Anisoptera, Dipterocarpus and Vatica (including species in Vietnam) was introduced (Kress et al., 2003). However, there is an unequal between results of analysis of nuclear DNA and chloroplast DNA as the position of species in phylogeny diagram (Figure 1).

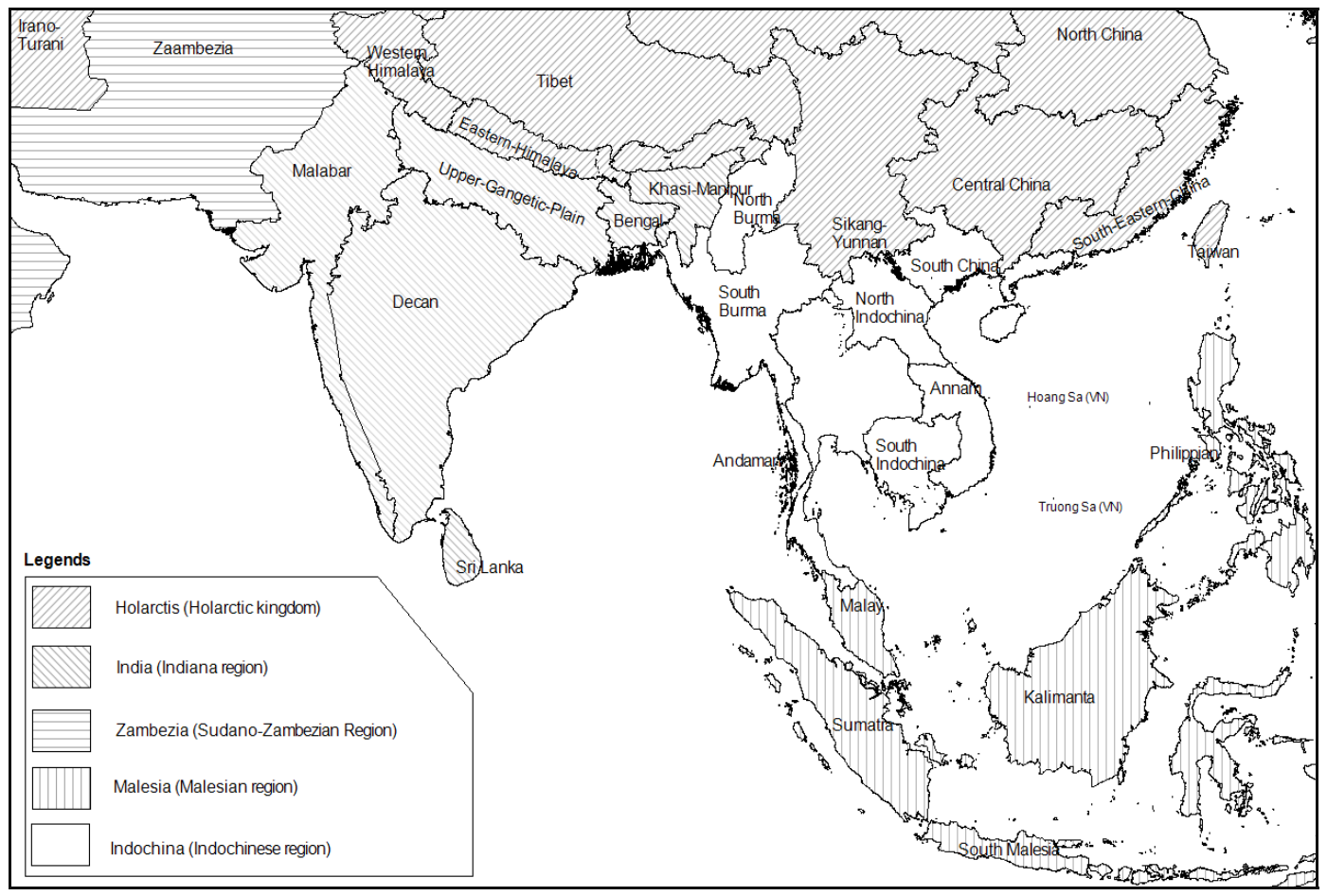

Figure 1. Diagram of floristic provinces in the Southeast Asia

(Drawing base on Takhtajan (1986) and Averyanov et al., 2003)

Takhtajan (1986) had established a global phytogeographical system with the basic unit of the floristic province. According to this system, Vietnam territory is situated in 2 kingdoms: Holarctic Kingdom (Eastern Asiatic region, Sikang-Yunnan floristic Province); and Paleotropical Kingdom (Indochina region with 4 floristic provinces as South China, North Indochina, Annam and South Indochina). However recent studies in Vietnam are some different from Takhtajan (1986), for example, the Asian phytogeographical elements 
cover whole the Asia (Le Tran Chan et al., 1999) or the Eastern Asian elements are in all eastern part of Asia on the Pacific coast (Nguyen Nghia Thin, 2004). Both of those elements have been not identified in the Takhtajan's system (1986); and moreover, the "phytogeographical element" conception has not been defined in this system. Most recently, detailing floristic provinces related to Vietnam territory, Averyanov et al. (2003) have divided the Annamese floristic province in Takhtajan's system (1986) into 2 subprovinces: Southern Annam and Central Annam. In that study, the species, especially endemic ones, for each province were inventoried but no species group in relation with the surrounding floristic provinces or regions was mentioned. Thus it is necessary to study phytogeographical distributions of some taxa for gradually establishing a phytogeographical map of Vietnam flora. In addition, the study on distribution of species, genera could give an idea such as: generating and overlapping points of the distributions of various species or genera, points would be checked with fossil evidence. On the contrary, the taxa distributing far from the overlapping point would be reputed as lately formed species. Based on these analyses, it would be established a phytogeographical phylogeny diagram, one of the important keys for phytogeographically mapping Vietnam flora.

\section{Materials and Methodology}

This study is basically synthesized the publications on Dipterocarps species existing in Vietnam and their distributional evidence in Vietnam and over the world, including online data of herbaria over the world and data published in Ashton P.S., 1982; Kress W.J. et al., 2003; Li X.W. et al., 2007; Nguyen Hoang Nghia, 2005; Nguyen Kim Dao, 2003; Nguyen Nga Phi, 2009; Pham Hoang Ho, 2001; Smitinand T.; 1969; 1990). The species are scientifically named by using The Plant List online version 1.1 (The Plant List, 2013). Distribution areas of the Dipterocarps taxa are defined by the interpolation method using 645 pieces of evidence (specimens and published information) of species found in Vietnam. The GIS tools are applied to develop distribution area of all subjects on the world floristic region map (Takhtajan, 1986), in particular within Vietnam territory; the boundaries of floristic provinces are based on the results of Averyanov et al., 2003 and the work of Takhtajan (1986) is added for determining the boundary of Central/Southern Annamese subprovinces. In this study, a method forming phytogeographical phylogeny diagram is suggested to regard the species in principle that the closely related species have close spatial distributions, but the result would only be ensured by comparing and checking with the phylogenetic diagram.

\section{Results}

\subsection{Distribution of Dipterocarps family in Vietnam}

The Dipterocarps species naturally distribute in most of Vietnam, except the Red River delta and Mekong River delta. Most of these species are found in the tropical climate with an elevation below $700 \mathrm{~m}$ (in the North) or bellow $1000 \mathrm{~m}$ (in the South) a.s.l. (Thai Van Trung, 1978). Some species can develop in both tropical and sub-tropical climate with an elevation above $700 \mathrm{~m}$ in the North or $1000 \mathrm{~m}$ in the South, such as Hopea siamensis, Pentacme siamensis, Dipterocarpus obtusifolius and Shorea roxburghi, etc., while some others are present only in narrow band of 500-700 m high in the North or 600-1000 $\mathrm{m}$ in the South, belonging to cold tropical climate such as Dipterocarpus grandiflorus, Hopea ferrea, Shorea henryana, Shorea hypochra... (Table 1). 
Vu Anh Tai, et al./Vietnam Journal of Earth Sciences 39 (2017)

Table 1. List of species of the Dipterocarps family in Vietnam

\begin{tabular}{|c|c|c|c|}
\hline No & Scientific name & Vietnamese name & Elevation \\
\hline 1 & Anisoptera costata Korth. & Vên vên & $<700$ \\
\hline 2 & Anisoptera scaphula (Roxb.) Pierre & Kiền kiền nhẵn & $<800$ \\
\hline 3 & Dipterocarpus alatus Roxb. ex G. Don & Dầu rái & $200-500$ \\
\hline 4 & Dipterocarpus baudii Korth. & Dầu lông & $200-800$ \\
\hline 6 & Dipterocarpus condorensis Pierre & Dầu cát & $200-500$ \\
\hline 5 & Dipterocarpus costatus Gaertn.f. & Dầu cát & $600-1000$ \\
\hline 7 & Dipterocarpus dyeri Pierre & Dầu song nàng & $<800$ \\
\hline 8 & Dipterocarpus grandiflorus Blanco & Dầu giọt tía & $500-700$ \\
\hline 9 & Dipterocarpus hasseltii Blume & Dầu rái & $<1000$ \\
\hline 10 & Dipterocarpus intricatus Dyer & Dầu trai & $500-700$ \\
\hline $11 \mathrm{a}$ & Dipterocarpus obtusifolius Teijsm. ex Miq. var. obtusifolius & Dầu trà beng & $500-1500$ \\
\hline $11 b$ & Dipterocarpus obtusifolius var. subnudus Ryan \& Kerr & Dầu song nàng & $<1300$ \\
\hline 12 & Dipterocarpus retusus Blume & Chò nâu & $800-1500$ \\
\hline $13 \mathrm{a}$ & Dipterocarpus tuberculatus Roxb. var. tuberculatus & Dầu đồng & $800-1000$ \\
\hline $13 b$ & Dipterocarpus tuberculatus var. grandifolius (Teijsm. ex Miq.) Craib & Dầu đồng lá to & $800-1000$ \\
\hline 14 & Dipterocarpus turbinatus Gaertn.f. & Dầu con quay & $30-1100$ \\
\hline 15 & Hopea chinensis (Merr.) Hand.-Mazz. & Táu vu & $100-1100$ \\
\hline 16 & Hopea cordata J. E. Vidal & Sưng đắng & $100-1100$ \\
\hline 17 & Hopea ferrea Pierre & Chò kiền kiền & $<700$ \\
\hline 18 & Hopea hainanensis Merr. \& Chun & Sao hải nam & $350-600$ \\
\hline 19 & Hopea helferi (Dyer) Brandis & Sao xanh & $<1000$ \\
\hline 20 & Hopea odorata Roxb. & Sao đen & $100-750$ \\
\hline 21 & Hopea pierrei Hance & Kiền kiền phú quốc & $<1000$ \\
\hline 22 & Hopea recopei Pierre & Chò chay & $<700$ \\
\hline 23 & Hopea reticulata Tardieu & Sao mạng & $200-600$ \\
\hline 24 & Hopea siamensis Heim & Kiền kiền & $<1200$ \\
\hline 25 & Hopea sp. & Sao đá & $<700$ \\
\hline 33 & Parashorea chinensis H. Wang & Chò chỉ & $100-1000$ \\
\hline 27 & Pentacme siamensis (Miq.) Kurz & Cà chắc xanh & $100-1500$ \\
\hline 28 & Shorea falcata J. E. Vidal & Sao lá lệch & $100-500$ \\
\hline 29 & Shorea guiso (Blanco) Blume & Chăn & $<600$ \\
\hline 30 & Shorea henryana Pierre & Bô bô & $<900$ \\
\hline 31 & Shorea hypochra Hance & Vên vên & 700 \\
\hline 32 & Shorea obtusa Wall. ex Blume & Cà chắc & $200-1000$ \\
\hline 26 & Shorea roxburghii G. Don & Sến cát & $>1300$ \\
\hline 34 & Shorea stellata (Kurz) Dyer & Chò đen & $<600$ \\
\hline 35 & Shorea thorelii Pierre & Trai & $50-550$ \\
\hline 36 & Vatica chevalieri (Gagnep.) Smitinand & Táu muối & $50-300$ \\
\hline 37 & Vatica cinerea King & Táu nước & $<900$ \\
\hline 38 & Vatica diospyroides Symingt. & Táu muối & $<900$ \\
\hline 39 & Vatica mangachopoi Blanco & Táu duyên hải & $<600$ \\
\hline $40 \mathrm{a}$ & Vatica odorata (Griff.) Symingt. subsp. odorata & Táu mật & $300-900$ \\
\hline $40 \mathrm{~b}$ & Vatica odorata subsp. brevipetiolata Phamh. & Táu lá nhỏ & $300-800$ \\
\hline 41 & Vatica pauciflora (Korth.) Blume & Táu ít hoa & $<700$ \\
\hline 42 & Vatica philastreana Pierre & Làu táu nước & $<700$ \\
\hline 43 & Vatica subglabra Merr & Táu nước & $100-900$ \\
\hline
\end{tabular}

\subsection{Phytogeographically regioning the Dip- terocarps family of Vietnam}

Analyzing 645 present sites of the Dipterocarps family of Vietnam shows that the distribution area of all members of this family in
Vietnam covers on 2 floristic kingdoms: Paleotropis (4 floristic regions, 14 floristic provinces) and Holartis (2 floristic regions, 6 floristic provinces) (Table 2). The Dipterocarps of Vietnam, first concentratedly distributed in Indochina province with 43 species and then 
Vietnam Journal of Earth Sciences, 39(3), 337-344

northwards expanded to Sikang - Yunnan with herein presence of Dipterocarpus retusus, D. turbinatus, Hopea chinensis, Parashorea chinensis (Li et al., 2007), Vatica diospyroides and V. subglabra (Nguyen Kim Dao, 2003) or westwards expanded to Sudano-Zambezian region with the Dipterocarpus turbinatus (Nguyen
Kim Dao, 2003) and was southwards limited in the Malesian region with 25 species. Among the floristic provinces, there are 5 provinces covering all Vietnamese territory: Sikang - Yunnan belonging to Holartis, South China, North Indochina, Annam and South Indochina belonging to the Indochinese region of Paleotropics.

Table 2. Distribution of species of Dipterocarps family of Vietnam in floristic units

\begin{tabular}{|c|c|c|c|c|c|c|c|c|c|c|c|c|c|c|c|c|c|c|c|c|c|}
\hline \multirow{4}{*}{ No } & \multirow{3}{*}{$\begin{array}{c}\text { Kingdom } \\
\text { Region } \\
\text { Floristic Province } \\
\end{array}$} & \multicolumn{5}{|c|}{ Holarctis: 8} & \multicolumn{15}{|c|}{ Paleotropis: 43} \\
\hline & & \multicolumn{4}{|c|}{ Eastern Asia: 6} & \multirow{2}{*}{ (a) } & \multicolumn{2}{|c|}{ India: 9} & \multicolumn{7}{|c|}{ Indochina: 43} & \multicolumn{5}{|c|}{ Malesia: 25} & \multirow{2}{*}{ (b) } \\
\hline & & $(1)$ & (2) & (3) & (4) & & (5) & (5) & (7) & $(8)$ & (9) & $(10)$ & (11) & (12) & (13) & (14) & (15) & (16) & $(17)$ & $(18)$ & \\
\hline & Number of species & 1 & 2 & 2 & 6 & 1 & 5 & 5 & 21 & 5 & 7 & 31 & 33 & 35 & 31 & 25 & 4 & 7 & 6 & 11 & 1 \\
\hline 1 & Anisoptera costata & & & & & & & & & & & + & + & + & + & + & + & + & + & + & \\
\hline 2 & A. scaphula & & & & & & + & & + & & & + & + & + & + & + & & & & + & \\
\hline 3 & Dipterocarpus alatus & & & & & & & + & + & & & + & + & + & + & + & & + & & + & \\
\hline 4 & D. baudii & & & & & & & & + & & & + & & + & + & + & & & + & + & \\
\hline 5 & D. condorensis $(*)$ & & & & & & & & & & & & & & + & & & & & & \\
\hline 6 & D. costatus & & & + & & & + & & + & & & + & + & + & + & + & & & & & \\
\hline 7 & D. dyeri & & & & & & & & & & & + & + & + & + & + & & & & & \\
\hline 8 & D. grandiflorus & & & & & & & & + & + & & + & & + & + & + & + & + & + & & \\
\hline 9 & D. hasseltii & & & & & & & & & & & + & + & + & + & + & + & + & + & + & \\
\hline 10 & D. intricatus $(* *)$ & & & & & & & & & & & + & + & + & + & & & & & & \\
\hline 11 & D. obtusifolius & & & & & & & & + & + & & + & + & + & + & + & & & & & \\
\hline 12 & D. retusus & & + & + & + & & + & + & + & & + & + & + & + & + & + & & + & + & + & \\
\hline 13 & D. tuberculatus & & & & & & + & & + & & & + & + & + & + & & & & & & \\
\hline 14 & D. turbinatus & + & + & & & + & + & & + & + & & + & + & + & + & + & + & & + & + & + \\
\hline 15 & Hopea chinensis & & & & + & & & & & & + & & + & & & & & & & & \\
\hline 16 & H. cordata $(*)$ & & & & & & & & & & & & & + & & & & & & & \\
\hline 17 & H. ferrea & & & & & & & & + & & & + & + & + & + & + & & & & & \\
\hline 18 & H. hainanensis & & & & + & & & & & & + & & + & + & & & & & & & \\
\hline 19 & H. helferi & & & & & & & & + & + & & + & + & & + & + & & & & & \\
\hline 20 & H. odorata & & & & & & & & + & + & & + & + & + & + & + & & & & & \\
\hline 21 & H. pierrei & & & & & & & & & & & + & + & + & + & + & & & & ? & \\
\hline 22 & H. recopei(**) & & & & & & & & & & & + & + & + & + & & & & & & \\
\hline 23 & H. reticulata $(* *)$ & & & & & & & & & & + & + & & + & & & & & & & \\
\hline 24 & H. siamensis(**) & & & & & & & & & & & + & & + & & & & & & & \\
\hline 25 & $\begin{array}{l}\text { Hopea sp. } \\
(*)(* * *)\end{array}$ & & & & & & & & & & & & + & & & & & & & & \\
\hline 26 & Parashorea chinensis & & & & + & & & & & & + & & + & + & & & & & & & \\
\hline 27 & Pentacme siamensis & & & & & & & & + & & & + & + & + & + & + & & & & & \\
\hline 28 & Shorea falcata $(*)$ & & & & & & & & & & & & & + & & & & & & & \\
\hline 29 & S. guiso & & & & & & & & & & & + & & + & + & + & & + & + & + & \\
\hline 30 & S. henryana & & & & & & & & + & & & + & + & + & + & + & & & & & \\
\hline 31 & S. hypochra & & & & & & & & & & & + & + & & + & + & & & & & \\
\hline 32 & S. obtusa $(* *)$ & & & & & & & & + & & & + & + & + & + & & & & & & \\
\hline 33 & S. roxburghii & & & & & & & + & + & & & + & + & + & + & + & & & & & \\
\hline 34 & S. stellata & & & & & & & & + & & & + & + & + & + & + & & & & & \\
\hline 35 & S. thorelii(**) & & & & & & & & + & & & + & + & + & + & & & & & & \\
\hline 36 & Vatica chevalieri(*) & & & & & & & & & & & & + & & & & & & & & \\
\hline 37 & V. cinerea & & & & & & & & & & & + & + & + & + & + & & & & & \\
\hline 38 & V. diospyroides & & & & + & & & & & & & + & + & & & & & & & & \\
\hline 39 & V. mangachapoi & & & & & & & & & & + & + & & + & & + & & + & & + & \\
\hline 40 & V. odorata & & & & & & & & + & & + & + & + & + & + & + & & & & & \\
\hline 41 & V. pauciflora & & & & & & & + & + & & & + & + & + & + & + & & & + & + & \\
\hline 42 & V. philastreana $(* *)$ & & & & & & & & & & & + & & + & + & & & & & & \\
\hline 43 & V. subglabra & & & & + & & & + & + & & + & & + & & & & & & & & \\
\hline
\end{tabular}


$\leftarrow$ Note: Floristic region: (a): Irano Turano, (b): Sudano-Zambezian; Floristic provinces: (1): Eastern Himalaya, (2): Khasi-Manipur, (3): Northern Burma, (4): Sikang-Yunnan, (5): Bengal, (6): Malabar, (7): Southern Burma, (8): Andaman, (9): South China, (10): Thailand, (11): North Indochina, (12): Annam, (12): South Indochina, (14): Malay, (15): Kalimanta, (16): Philippian, (17): Sumatra, (18): South Malesia; (*): Endemic for Vietnam; $(* *)$ : Endemic for Indochina; $(* * *)$ : Hopea sp. (according to Nguyen Hoang Nghia, 2005)

None of the Dipterocarps species found in Vietnam is endemic for any floristic province of the Holartis and there is a North - South trend separating these species. The appearance of Dipterocarps species in South China province seems to be result from a distributional expansion of those in Indochinese floristic region. There are 5 endemic species for 3 provinces of the Indochinese floristic region: Dipterocarpus condorensis for North Indochina; Hopea sp., Vatica chevalieri (Nguyen Hoang Nghia, 2005) for South China; Hopea cordata and Shorea falcata (Smitinand et al., 1990; Nguyen Hoang Nghia, 2005) for Annam; 7 other species are endemic to the Indochinese floristic region: Dipterocarpus intricatus, Hopea recopei, $H$. reticulata, $H$. siamensis, Shorea obtusa, S. thorelii and Vatica philastreana (Smitinand et al., 1990).

Based on the comparison between the distributions of Dipterocarps species found in Vietnam and those in other areas, in the Indochinese floristic region, the 2 provinces of Thailand and Southern Burma have the close relationship with 3 Indochinese floristic provinces covering Vietnam (North Indochina, Annam and South Indochina). Moreover, Malay floristic province in the Malesian floristic region also has the good relationship with these 3 provinces. To explain this phenomenon, there may be a reason directly connecting Malay and Indochina Peninsulas. The other floristic provinces of the Malesian and Indochinese regions have a small number of Dipterocarps species found in Vietnam. Therefore, together with Thailand, Eastern Burma and Malay, the 3 floristic provinces covering Vietnam as the North Indochina, Annam and South Indochina are core distribution area of the Dipterocarps family through the species discovered in Vietnam.

\subsection{Phytogeographic phylogeny diagram of Dipterocarp family in Vietnam}

A phytogeographical distribution of Dipterocarps genera found in Vietnam is formed by combining the distributions of their species (Figure 2). Comparing these data with the distribution area of genera in Dipterocarps family of Vietnam published by Smitinand et al., 1990, shows that:

Genus Anisoptera has 2 species limitedly distributing in Paleotropis, including the Indochinese and Malesian regions and a small part in the Indiana region (Bengal floristic province, adjacent to Indochinese region). According to data of Nguyen Kim Dao (2003), it is new record of genus distribution in Indiana region with species of $A$. scaphula.

Genus Dipterocarpus with 12 species has most distribution area of Dipterocarp family of Vietnam except Sudano-Zambezian region. Its distribution area expands to the Southern of the China, to the Holartis kingdom: Dipteorcarpus retusus distributed in Sikang Yunnanese floristic province (Li X.W et al., 2007).

Genus Hopea with 11 species has relatively wide distribution, from the centre of the Indochinese floristic region: northwards to Sikang - Yunnanese floristic province of Holartis, mostly expanding in Vietnam and somewhere in Yunnan administrative province of the China; southwards to the Southern Malesian floristic provinces, excluding the Philippine, Sumatra and Kalimantan floristic provinces. In comparison with the data of Smitinand et al., 1990, there is no evidence 
Vietnam Journal of Earth Sciences, 39(3), 337-344

for distribution of this genus in the Indian region.

Genus Parashorea has only one species distributing from Indochinese floristic region to Sikang - Yunan province of the Holartis kingdom and to Malay province in the Malesiana floristic region. The study of Smitinand et al., 1990) gave similar result.

Genus Pentacme has only one species limitedly distributing within floristic provinces of Indochinese region and in Malay floristic province. This is also similar with the data of Smitinand et al., 1990 with the species Shorea siamensis (it is a synonym of Pentacme siamensis).

Genus Shorea has 8 species, concentratedly distributing within the Indochinese and
Malesian floristic region except the Kalimantan floristic province, expanded to the Indianan floristic region at Malabar floristic province with one species as $S$. roxburghii; and there is no species discovered in the Holartis. This result corresponds to that of Smitinand et al., 1990.

Genus Vatica with 8 species concentrated distributes within the Indochinese and Malesian floristic regions, expanding to Malabar province of Indian floristic region and to Sikang - Yunnan and Southeastern China provinces of Horiatis kingdom, but there is no evidence found in Kalimantan and Sumatra provinces of Malesian floristic regions. This result is also similar with the data of Smitinand et al., 1990.

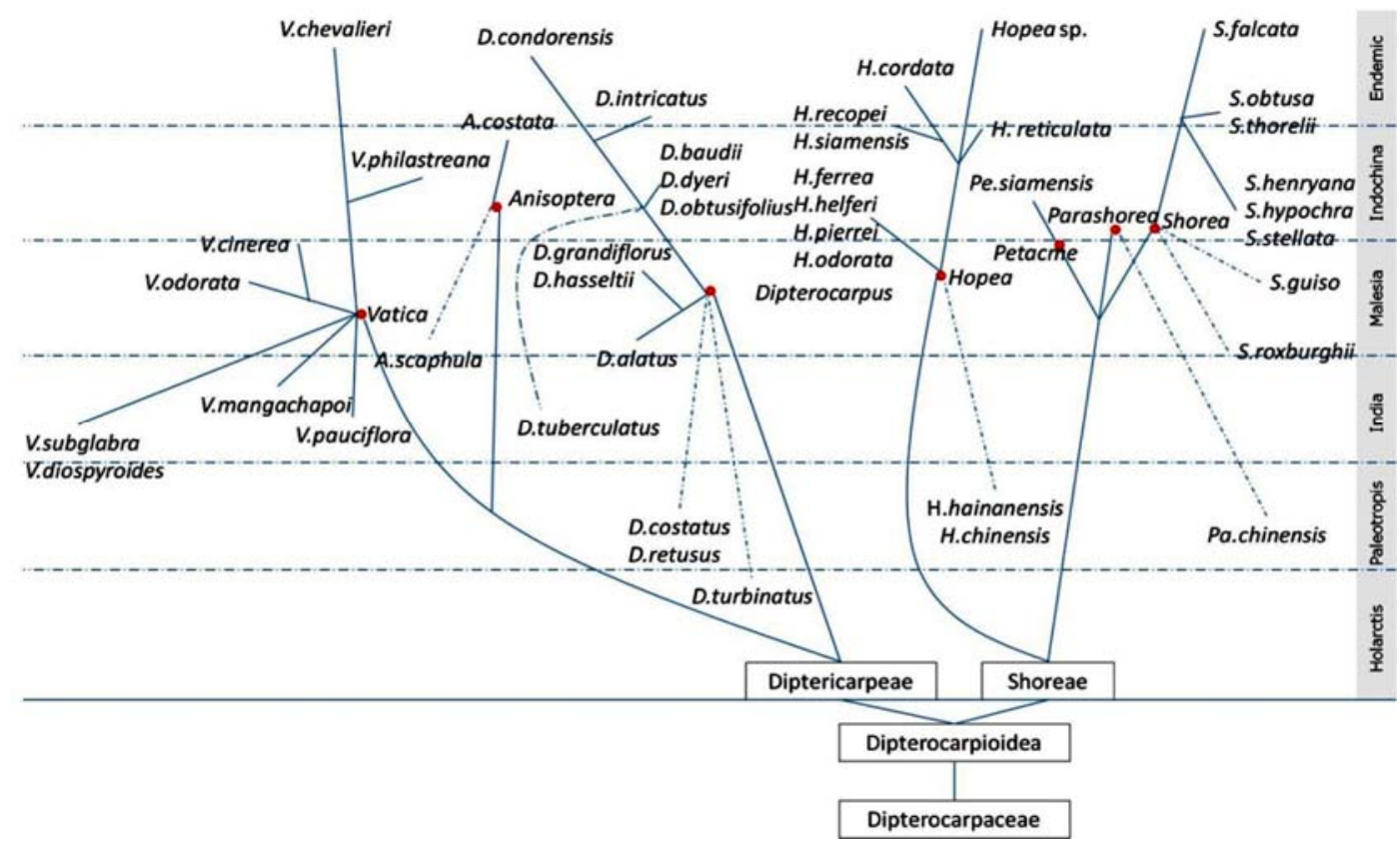

Figure 2. Phytogeographic phylogeny diagram of Dipterocarps family found in Vietnam

\section{Conclusions}

Analyzing geographical distribution of the Dipterocarps family of Vietnam shows that family has concentrately distributed in Indochinese floristic region, concurring with originative centre in Burma (Myanmar). There are 5 endemic species for 4 floristic provinces, covering whole Vietnam territory, belonging to Indochinese floristic region, while this region has total 12 endemic species of Dipterocarps of Vietnam. In addition, it also suggests that the species ancestors of Dipterocarps in Vietnam appeared in Holarctis due to the distributional 
Vu Anh Tai, et al./Vietnam Journal of Earth Sciences 39 (2017)

expansion from Indochinese floristic region. All genera had originated from the Indochinese floristic region. In comparison with data of Smitinand et al. (1990), the genera distributions are firstly recorded in Indian floristic region with Anisoptera, in the Sikang - Yunnanese floristic province of Eastern Asian floristic region with the Dipterocarpus.

Combining phytogeographical species, genera data and genetic data enables to form the phytogeographical phylogeny diagram, reconstructing the evolution of the Dipterocarps found in Vietnam through the time with natural conditions such as geology, climate, geography, etc. In some particular cases, the phytogeographic phylogeny diagram has certain advantages; it would be replaceable or even better than genetic phylogeny diagram. The phytogeographic phylogeny diagram is more useful tool in case of deficiency of genetic data.

\section{References}

Angiosperm Phylogeny Group, 2009. An update of the Angiosperm Phylogeny Group classification for the orders and families of flowering plants: APG III. Botanical Journal of the Linnean Society, 161(2), 105-121.

Ashton P.S., 1982. Dipterocarpaceae. In: Van Steenis C.G.G.J., 1979-1983, Flora Malesiana Vol. 9, part 2, Dipterocarpaceae. Martinus Nijhoff Publisher, The Hague, London, 250p.

Averyanov L.V., Phan K.L., Nguyen T.H., Harder D.K., 2003. Phytogeographic review of Vietnam and adjacent areas of Eastern Indochina, Komarovia, Saint Petersburg, 3, 1-83.

Kress W.J., DeFilipps R.A., Farr E. and Yin D.Y.K., 2003. A checklist of the trees, shrubs, herbs and climbers of Myanmar. National Museum of Nature History, Washington DC, 45, 1-590.

Le Tran Chan (Editor), 1999. Some characteristics of the flora of Vietnam. Science and Technique publishing house, Hanoi, 305p (Vietnamese).

Li X.W., Li J., Ashton P.S., 2007. Dipterocarpaceae. In: Wu Z.Y., Raven P.H. (Hrsg.). Flora of China. Missouri Botanical Garden Press, St. Louis, 13, 48-54.

Nguyen Hoang Nghia, 2005. Dipterocarps of Vietnam. Agriculture Publishing House, Hanoi, 100p.

Nguyen Kim Dao, 2003. "Dipterocarpceae Blume, 1825 " in Checklist Plant species of Vietnam. Agricultural Publishing House, Hanoi, 2, 328-340 (Vietnamese).

Nguyen Nga Phi, 2009. Molecular phylogeny of Southeast-Asian Dipterocarps belonging to tribe Dipterocarpeae (family Dipterocarpaceae) based on noncoding sequence data of chloroplast and nuclear DNA. Department of Forest Genetics and Georest Tree Breeding, Büsgen Institute, Faculty of Forest Science and Forest Ecology, Georg-August University of Göttingen. Göttingen, 142p.

Nguyen Nghia Thin, 2004. Methods in Botanical Research. HNU publishing house, Hanoi, 172p. (Vietnamese).

Pham Hoang Ho, 2001. Illustration Flora of Vietnam, Youth Publishing House. Ho Chi Minh City, 2, 1022p (Vietnamese).

Smitinand T., 1969. The distribution of Dipterocarpaceae in Thailand. National History Bull. Siam Soci., 23, 67-75.

Smitinand T., J.E. Vidal, P.H. Ho, 1990. Flore du Cambodge, du Laos et du Vietnam, 25, Diptérocarpacées. Muséum National d'Histoire Naturelle, Paris, 123p (French).

Takhtajan A. (Translated by Theodore J. Crovello), 1986. Floristic Regions of the World. University of California Press, 544p.

Thai Van Trung, 1978. Tropical Forest Ecology systems of Vietnam. Science and Technique publishing house, Hanoi, 314p (Vietnamese).

The Plant List (Version 1.1.), 2013. Dipterocarpaceae. http://www.theplantlist.org. 